\title{
Natural Disasters and Economic Growth: A Review
}

\author{
Nourin Shabnam
}

Published online: 21 June 2014

(c) The Author(s) 2014. This article is published with open access at Springerlink.com

\begin{abstract}
This article provides a literature review of economic growth theories and identifies the implications of growth theories in addressing potential impacts of uncertain shocks, that is natural disasters. The extant literature seems inconclusive: some find positive effects of natural disasters on economic growth and others suggest either negative or no effect as such. Using a large panel dataset of 187 countries observed from 1960 to 2010, this article shows that the total number of people affected by floods significantly decreases the annual GDP per capita growth rate, whereas the death toll from floods has no substantial effect on the annual GDP per capita growth rate. One thousand in every one million people affected by floods decrease the GDP per capita growth rate by $0.005 \%$. This result is plausible, as floods are likely to create havoc in people's livelihoods rather than claim a high human death toll. The article outlines future directions of research in the field of natural disaster augmented growth empirics.
\end{abstract}

Keywords Damages and losses - Economic growth $\cdot$ Flood impacts $\cdot$ Natural disasters

\section{Introduction}

At the root of all economic research is the question of how to best eliminate human wants. The fundamental rationale of studying economics is to know why some individuals are rich while others remain poor. In a macroeconomic context, this extends to why some countries have grown

N. Shabnam $(\square)$

School of Accounting, Economics and Finance,

Deakin University, Burwood, VIC 3125, Australia

e-mail: nshabnam@deakin.edu.au rich while others remain poor. Some economists (Ramsey 1928; Solow 1956; Swan 1956; Koopmans 1963; Cass 1966; Kuznets 1973; Romer 1986; Lucas 1988, Lucas Jr. 1990; Barro 1991; Mankiw et al. 1992; Hansen and Prescott 2002; Durlauf et al. 2005; Galor 2005) have answered this question in a way that has facilitated the emergence of new branches of macroeconomics referred to as growth theory. Nonetheless, macroeconomists have not explored the deep-determinants that are responsible for delineating the rich and the poor. Temple (1999) pointed out that the study of economic growth has been given very little importance and often added as a brief last chapter in macroeconomic textbooks, and rarely studied outside of development economics.

Natural disasters often undo many years of physical as well as human capital accumulation and can lead to slowing down the speed of convergence towards a steady state economy within the country context. The world has recently faced a sharp surge in the frequency of extremely severe natural disasters, and the effects have been devastating. More than 7,000 major disasters have been recorded since 1970, causing at least USD 2 trillion in damages, killing at least 2.5 million people, and adversely affecting societies (CRED 2010). Some $75 \%$ of the world's population live in areas affected at least once by natural disaster between 1980 and 2000 (Pelling et al. 2004). Over 165,000 people died in the tsunamis of Southeast Asia (CRED 2010). Hurricane Katrina and Hurricane Andrew resulted in total insured losses to property of approximately USD 66.3 billion and USD 23.7 billion respectively (Kahneman and Kunreuther 2008). These statistics alone make natural disasters a high research priority for growth economists to identify optimal policies for addressing the impacts of such rapid onset events, especially in the context of developing countries. 
Given the critical relationship between natural disasters and economic growth, this article provides a literature review and some empirical findings and identifies the implications of economic growth theories for addressing the potential impacts of natural disasters. Section 2 reviews literature about the effects of natural disasters on economic growth. Section 3 considers the empirics of growth theories and natural disasters highlighting different empirical methods and problems associated with growth econometrics in general. Section 4 describes an example dataset and variables and presents the econometric modeling technique used to estimate the effects of flood disasters on economic growth. Section 5 outlines the empirical findings and their associated inferences.

\section{Literature Review: The Economics of Natural Disasters}

Do natural disasters have effects on economic growth? Much has been published in the field of growth theories as well as about the impacts of natural disasters. However, some studies have analyzed the effects of natural disasters on economic growth. Natural disasters receive little attention in growth literature. Zenklusen (2007) pointed out that the literature on the topic is diverse: a variety of academic disciplines propagates a spectrum of perspectives that fundamentally differ in both analytical approaches and findings. Given this scenario, this article reviews the existing literature related to growth theories that contributes towards explaining the causal relationship between natural disasters and economic growth and identifies both positive and negative consequences of natural disasters on economic growth through scientific empirical investigation.

The reciprocal association between natural and manmade disasters and growth of economies was first described by Mill (1848, p. 74-75): "What has so often excited wonder [is] the great rapidity with which countries recover from a state of devastation; the disappearance, in a short time, of all traces of the mischiefs done by earthquakes, floods, hurricanes, and the ravages of war. An enemy lays waste a country by fire and sword, and destroys or carries away nearly all the moveable wealth existing in it: all the inhabitants are ruined, and yet in a few years after, everything is much as it was before." That is, any catastrophic shock-for instance, civil wars or natural disasters-has an adverse immediate effect on the capital stock of a country; however, such destruction is recovered in the long-run.

Cavallo et al. (2013) mentioned that the growth empirics do not provide a definite answer on the relationship between natural disasters and economic growth. According to the traditional neoclassical growth models, the destruction of capital stock due to natural disasters is unlikely to affect the rate of technological progress; however it may boost short-run economic growth, possibly because it moves countries away from their steady-state levels of macroeconomic objectives. Unlike the neoclassical growth models, the endogenous growth models pose a radical view that natural disasters may lead to a higher economic growth, as the shocks of natural disasters can act as catalysts for reinvestment and improve the productivity of capital stock (see, for example, Caballero and Hammour 1994; Schumpeter 1942).

According to Fisker (2012), the existing literature on the economic consequences of natural disasters is surprisingly inconclusive given that all recent studies have built their analyses on the same data source-EM-DAT-and most studies focus their attention on 5-year GDP growth rates. Some analysts have arguments for positive effects of natural disasters on economic growth (Albala-Bertrand 1993; Skidmore and Toya 2002; Loayza et al. 2009), and some suggest negative effects (Raddatz 2007; Loayza et al. 2009; Noy 2009; Cavallo et al. 2010).

The nexus between economic growth and natural disasters was empirically tested by Albala-Bertrand (1993) using regression methods. The study includes a model of disaster occurrence and reaction with a sample of 28 large natural disasters that occurred from 1960 to 1979 in low- or middle-income countries. Earthquakes constituted around half the incidents and droughts, cyclones, floods, and tsunamis accounted for the rest. The study concluded that natural disasters have no effect on the growth of an economy in the long run, but a slightly positive one in the short run. The reason for the latter result is supposedly an "endogenous response mechanism" that takes place within the country although this was not tested empirically. The study is based on a before-after estimation that compares the GDP per capita in the country. In combination with the small sample size, the conclusions in Albala-Bertrand (1993) may not be very robust. In Barro and Lee (1993), most of the macroeconomic factors are positively associated with growth and negatively associated with disaster risk: disasters reduce the investment rate and raise government consumption expenditure. They also increase the black market premium on foreign exchange as well as the frequency of revolutions.

Both Skidmore and Toya (2002) and Loayza et al. (2009) found that climatic disasters have a positive impact on economic growth whereas geological events (such as earthquakes) do not have any significant impact. Using a cross-section of 89 developed and developing countries, Skidmore and Toya (2002) found partially a direct relationship between the frequency of climatic disasters and total factor productivity growth. The results for geological 
disasters indicate no significant effect on the growth of total factor productivity (TFP). The primal contribution of Skidmore and Toya (2002) to the literature on the economics of natural disasters is that they directly assessed the relationship between foreign technology absorption and catastrophic events. Their study shows that natural disasters update capital stock and encourage the adoption of new technologies, which lead to improved TFP and the growth of the gross domestic product (GDP). After controlling for relevant determinants, it is shown that the frequency of climatic disasters is positively associated with TFP growth, human capital accumulation, and GDP per capita growth. One of the reasons behind this association may be explained by the adoption of new technologies. Once natural disasters destroy the capital stock of a country, the economic incentives to replace it with a more improved technology are higher. In other words, natural disasters may provide opportunities to upgrade capital stock that may lead to higher rates of TFP and GDP per capita growth. Such explanations can be regarded as a good example of Schumpeterian creative destruction (see Schumpeter 1942). To the best of my knowledge, Skidmore and Toya (2002) offer arguably the most comprehensive piece of empirical research of measuring the direct longrun impacts of natural disasters on economies.

Cuaresma et al. (2008) examined the correlation between the frequency of natural disasters and long-run economic growth and found that the degree of catastrophic risk has a positive effect on the volume of knowledge spillovers that take place between industrialized or developed countries and agro-based or developing countries. They identified natural disasters as creative destruction.

Arguments for adverse effects of natural disasters on economic growth are partially suggested by Raddatz (2007), Noy (2009), Loayza et al. (2009), and Cavallo et al. (2010). Noy (2009) found adverse effects only for low-income or developing countries and only in the short term; Cavallo et al. (2010) limited their study to rare catastrophic events; and Raddatz (2007) found that only climatic and humanitarian disasters affect economic growth negatively. Loayza et al. (2009) applied a dynamic Generalized Method of Moments (GMM) estimator to a 1961-2005 cross country panel dataset in order to estimate the effects of several types of natural disasters on economic growth in different sectors of the economy. Using the EM-DAT, they identified adverse economic impacts only for droughts, whereas floods have vital positive impacts on the economic growth rate.

Okuyama (2003) presented a significant link between mainstream growth research and empirical studies on macroeconomic disaster effects. He argued that older capital stock is more vulnerable to natural disasters, and thus the upgradation of these obsolete capital equipments may trigger a positive productivity shock that may reshape the whole economy with better efficiencies in producing goods and services. These may lead to a permanent increase in the growth rate of GDP per capita of a country.

Dacy and Kunreuther (1969) proposed a theoretical framework suggesting that disasters have visible negative impacts on economic growth. Ellson et al. (1984) built a regional econometric model and estimated that disasters incur both damages and losses towards aggregate economic activities. Yezer and Rubin (1987) conducted a study showing that disasters affect local economies negatively, which may play an insignificant role at the aggregate level. Gourio (2008) found an unstable relationship between the prices of capital stocks and natural disasters. Nakamura et al. (2010) concluded that disasters increase uncertainty in consumption growth; more specifically, on an average consumption falls by $30 \%$ in the short run, and by $15 \%$ in the long run. Loayza et al. (2009) explained that disasters do not always affect economic growth negatively, but differently across disasters and different sectors of the economy.

Because few growth economists have related growth theories to natural disasters, the empirics regarding natural disasters are still in their beginnings. This article aims to contribute to understanding the effects of natural disasters on economic growth in terms of some significant economic indicators and to supporting policy makers who are engaged in disaster risk reduction process of a country.

\section{Empirics of Growth Theories: Available Methods and Potential Problems}

The empirics of growth theory are vastly dependent on panel data techniques. These techniques allow controlling for omitted variables that are persistent over time. Moreover, the panel models can control the unobserved heterogeneity in the initial level of efficiency (Temple 1999). Another advantage is that several lags of the regressors can be used as instruments that can eliminate the measurement errors, and on the whole, endogeneity biases from the estimation (Caselli et al. 1996).

The growth empiricists often use fixed effects approaches to control for the time invariant effects within a country; and that vary across countries. Moreover, in growth literature, there is no common consensus on whether one should use annual data, or five- or ten-year averages to offset business cycle effects from the model estimation. Temple (1999) found that most Growth Economists had used five- or ten-year averages, which seems that controlling for business cycle effects in growth empirics is indispensable to obtain reliable estimates.

Some Time-series Economists argue that controlling for fixed effects in a panel model throws away useful 
information on the heterogeneity across countries. This uncovers the weaknesses of the panel method in estimating the effect of growth across countries. Alternatively, they suggest that one should analyze the growth empirics country-by-country, rather than putting all countries under a cross-section setting.

Irrespective of different empirical frameworks, there are in general substantial problems in estimating growth-related econometric equations. One of the prime problems associated with empirical work on economic growth is the parameter heterogeneity. Harberger (1987) raised the question of what do Thailand, the Dominican Republic, Zimbabwe, Greece, and Bolivia have in common that can convince one to put them in the same regression model? For instance, the investment return is likely to be lower in war-torn and unstable countries than in peaceful ones. This feature of slope variance across countries would render conventional estimates inconsistent. To address this problem, Durlauf et al. (2005) employed a unique country grouping, and as a result, the parameters differ widely in the model. They also suggested that the economic growth does not follow a linear trend across countries, and hence, it is not appropriate to analyze new growth theories using linear regression models. Some imaginative methods for detecting heterogeneity are now being utilized that include interaction terms, regression trees, robust estimation, dummy variables, and sample splits.

One inevitable problem regarding growth econometrics is associated with outliers and the remedy is provided by robust regression technique. Rousseeuw and Leroy (1987) indicate that robust estimation procedures are essential to identify the most reliable sample of the dataset and these can help identify possible outliers in the estimation model. The exclusion of identified outliers will not only help generalize the findings of growth research across countries, but will also facilitate understanding more on countries with different growth trajectories (Temple 1998).

The problem of endogeneity tends to be one of the most frequently expressed concerns in the growth empirics. To avoid this problem, researchers in general include initial values of the relevant variables in the model. This is not quite as robust as researchers seem to accept: it may solve the problem of endogeneity at a greater extent but not as a whole (Temple 1999). Barro and Sala-i-Martin (1992) used instrumental variables to avoid these problems. However, there is a shortage of good instruments.

In spite of a large volume of literature, the empirics of growth theories have yet to advance to a mature stage. One of the prime reasons is associated with actual data heterogeneity across countries. Modern growth theories are built by exaggeratedly emphasizing the investment in physical and human capital and activities related to research and development. However, these productive factors have failed to explain the growth path of Sub-Saharan countries, for example. Future directions of growth empirics need to analyze the deeper determinants of growth including institutional and geographic factors.

Most growth theories consider technological progress and total factor productivity as given, that is exogenously determined by the model. Hence, most developing countries fail to utilize growth theories for answering practical policy questions. One interesting future direction of growth theories would be endogenizing technological factors into the model framework.

A few growth theories incorporated demographical issues, though they fail to address why population growth rates increase in the early stages of development and decrease in the more advanced stages of development. Galor and Weil (2000) argued that this may be explained by a quantity-quality trade-off between the numbers of children a family has versus the amount of human capital invested in each child. In addition, this may be due to the fact that the shift from the Malthus to the Solow technology entails households transiting from the home-based farms, where children are likely to be used as labors, to corporatebased production plants, where they are rarely treated as capital assets (see Hansen and Prescott 2002).

Development economists usually compare different types of growth and their effects on welfare. Useful progress can be made by relating impacts of natural disasters on national wealth and real GDP growth. In general, natural disasters adversely affect accumulated national wealth, whereas they support an increase in the GDP growth rate (Aghion and Howitt 1992; Cuaresma et al. 2008; Noy and Vu 2010). Natural disasters can raise economic growth and decrease social welfare at the same time. It would be important to address the relationship between natural disasters, GDP growth rate, and social welfare within one framework.

Empirical research on growth theories is accelerating mostly by utilizing panel data and cross-section regression methods. Macroeconometric models including vector autoregressive (VAR) as well as structural econometric models under a simultaneous equation system can be applied to check the robustness of growth theories linking with other sectors of the economy.

\section{Data and Estimation Model}

In this empirical investigation, I estimated the impact of floods-in terms of the death toll and the total number of people affected by floods - on the annual GDP per capita growth rate. I employed a large panel dataset of 187 countries, observed from 1960 to 2010 . This study used the EM-DAT dataset for flood events, which has been widely 
Table 1 Descriptive Statistics

\begin{tabular}{llll}
\hline Variable & Mean & SD & Observations \\
\hline $\begin{array}{l}\text { Total death tolls per thousand people } \\
\text { in floods }\end{array}$ & 0.004 & 0.082 & 13,698 \\
$\begin{array}{l}\text { Total affected per thousand people } \\
\quad \text { in floods }\end{array}$ & 3.948 & 35.690 & 13,698 \\
GDP per capita growth (annual \%) & 2.051 & 6.329 & 7,658 \\
Log of real GDP per capita & 8.281 & 1.278 & 8,647 \\
\hline
\end{tabular}

used in many studies (Kahn 2005; Cavallo et al. 2010; Keefer et al. 2011). According to the EM-DAT (CRED 2010), a flood event is recorded into the dataset if a flood incident satisfies any of the following four conditions: (1) 10 or more people are reported killed; (2) 100 or more people are reported affected; (3) there is a call for international assistance; (4) there is a declaration of a state of emergency. Such flexible conditions assure the maximum level of data coverage for EM-DAT. It is important to note that EM-DAT maintains data on the human dimensions of an event (that is, the total number of people who died, are injured, made homeless, or are otherwise affected), not on an event's physical attributes (for example, river water level and amount of rain). Two variables associated with flood events are used here: number of people killed and total number of people affected (that is, the sum of the total number of injured, homeless, and otherwise affected people) in floods for each country in a given year.

Data on GDP per capita in the included countries was taken from the World Development Indicators (World Bank 2013). The population size of the included countries was retrieved from the Penn World Tables (PWT), version 7.0 (Heston et al. 2011). Table 1 contains the descriptive statistics for the key variables used here.

To track the relationship between floods and economic growth rate, the following specification is formulated:

$y_{i, t}=\alpha_{i}+\varphi_{i} t+\theta_{t}+\beta_{1}$ Killed $_{i, t}+\beta_{2}$ Affected $_{i, t}+\varepsilon_{i, t}$

where $y_{i, t}$ stands for the growth rate of real GDP. This is the outcome variable that is widely used in the economic growth literature. Killed ${ }_{i, t}$ is the total death toll and Affected $_{i, t}$ is the total number of people affected by floods in country $i$ at time $t$. Both variables are normalized by population size. On the right-hand side, we control for country-specific heterogeneity $\left(\alpha_{i}\right)$, the country-specific time trend $(t)$ and its associated coefficient $\left(\varphi_{i}\right)$, and timevariant shocks that are common across countries $\left(\theta_{t}\right)$. The main coefficients of interest are $\beta_{1}$ and $\beta_{2}$ that represent the effects of the death toll and total number of people affected by floods respectively. The term $\varepsilon_{i, t}$ captures the residual of the estimation framework.
Table 2 GDP per capita growth rate, death toll, and total affected people in floods

\begin{tabular}{|c|c|c|c|c|}
\hline & \multicolumn{4}{|c|}{$\begin{array}{l}\text { Dependent Variable: GDP per capita growth } \\
\text { (annual \%) }\end{array}$} \\
\hline & (1) & (2) & (3) & (4) \\
\hline $\begin{array}{l}\text { Total death toll per } \\
\text { thousand people } \\
\text { in floods, } t\end{array}$ & $\begin{array}{r}-1.377 \\
(1.62)\end{array}$ & & $\begin{array}{r}-0.985 \\
(1.41)\end{array}$ & $\begin{array}{r}-0.879 \\
(1.22)\end{array}$ \\
\hline $\begin{array}{l}\text { Total affected per } \\
\text { thousand people } \\
\text { in floods, } t\end{array}$ & & $\begin{array}{l}-0.005^{* *} \\
(2.08)\end{array}$ & $\begin{array}{c}-0.005^{* *} \\
(2.02)\end{array}$ & $\begin{array}{c}-0.004 * \\
(1.95)\end{array}$ \\
\hline $\begin{array}{l}\text { Log of real GDP } \\
\text { per capita, } t\end{array}$ & & & & $\begin{array}{l}5.797 * * * \\
(8.52)\end{array}$ \\
\hline $\begin{array}{l}\text { Country fixed } \\
\text { effects }\end{array}$ & Yes & Yes & Yes & Yes \\
\hline Country time trend & Yes & Yes & Yes & Yes \\
\hline $\begin{array}{l}\text { Common time } \\
\text { effects }\end{array}$ & Yes & Yes & Yes & Yes \\
\hline Observations & 7,658 & 7,658 & 7,658 & 6,910 \\
\hline
\end{tabular}

Ordinary least squares estimation. In parentheses are the robust standard errors clustered at the country level. $t$ stands for time (year) * Significant at $10 \%$ level; ** significant at $5 \%$ level; *** significant at $1 \%$ level

To remove the effect of country-specific heterogeneity from the model, country dummies are used: 1 if the observation relates to the same country and 0 otherwise. That is, each country has a dummy variable. For capturing the country-specific time trend, a series of dummy variables are used by segregating "years" within each country. With respect to the time-variant shocks, time dummies are used: 1 if the observation relates to the same year irrespective of its country origin and 0 otherwise. ${ }^{1}$

\section{Results and Discussion}

Table 2 shows the relationship between flood indicatorsdeath toll and total affected people in flood events for each country in a given year-and the annual growth rate of GDP per capita. Column 1 indicates that the death toll in floods has no significant effect on GDP per capita growth, possibly because this specification does not control for other potentially significant variables that may create omitted variable bias in the estimation. To address this issue, we augment our specification of column 1 in several ways provided in columns 3 and 4 .

In column 2, the same specification is used as in column 1 except that death toll is replaced by total affected people in floods. The total number of affected people in flood

\footnotetext{
${ }^{1}$ See Brückner and Ciccone (2011) for further details on the estimation technique.
} 
events has a substantial impact on the GDP per capita growth rate, which is significant at $5 \%$ level. One thousand affected people in every one million in floods decreases GDP per capita growth by $0.005 \%$. This result is explained by the fact that floods more typically create havoc in people's livelihoods rather than claim a high human death toll.

In column 3, we added both death toll and total affected people in floods on the right-hand side of the estimation model to check the robustness of findings obtained in columns 1 and 2. The empirical model estimated in column 3 verified that total number of affected people in floods affects the GDP per capita growth rate significantly, whereas the death toll in floods has no significant effect.

This empirical specification may have some caveats. For instance, one can argue that the intensity of floods in claiming human lives and affecting livelihoods may largely depend on existing disaster risk mitigation measures - that is, river embankment, early warning, emergency shelters, and post-disaster recovery and reconstruction interventions. To address this issue, we control for log of real GDP per capita, assuming that this will tease out the heterogeneous variation in economic development. Controlling for $\log$ of real GDP per capita, column 4 shows that the total number of affected people in floods significantly affects the GDP per capita growth rate whereas the death toll in floods has no substantial effect on annual GDP per capita growth.

\section{Conclusion}

Given the complex relationship between natural disasters and economic growth, researchers need to examine the potential effects of natural disasters in three distinctive phases: short-run (for example, emphasizing political transitions through economic growth), medium- to longrun (for example, focusing directly on natural disasters and economic growth), and very long-run (for example, highlighting deeper indicators of growth). On the basis of the literature review conducted, this article discusses the data and measurement issues as well as the estimation framework regarding natural disasters and economic growth within the same framework.

Growth econometrics is an area of research that is still growing. Addressing the effects of natural disasters through growth theories has yet to be discovered comprehensively. Natural disasters have been only marginally covered in the mainstream macroeconomic literature (see, for example, Horwich 2000). However, recently the trend of incorporating natural disasters into the macroeconomic sphere becomes visible. Nonetheless, considering the wealth of theoretical concepts and empirical methodologies that could be applied to the study of disasters, the finding that economic disaster research is in its infancy is surprising. It could be an extensive and interesting field of research. Illustrative of research agenda of disaster-related problems that are rarely studied from a socioeconomic point of view include the gender and political economy of disasters, the gendered terrain of natural disasters and economic growth, creative destruction versus destructive creation, the estimation of potential consequences of different types of disasters on different groups of population, the role of better institutions towards mitigating disaster risks and accelerating socioeconomic outcome, including aspects such as preparedness, emergency response, and recovery and reconstruction interventions.

Appropriate use of economic theories may uphold analytical rigor, lessen complexity, and formulate simple but effective lines of argument. This may contribute to addressing central issues of current disaster research on a more plausible theoretical foundation. As Albala-Bertrand (1993) points out, natural disasters are primarily a problem of development, they are not necessarily a problem for development. Since the poor suffer most from the effects of such catastrophes, research should more analytically address the mitigation and recovery aspects of disaster risks.

Acknowledgments I thank the two anonymous referees and the editors for comments that substantially improved the article. I am also grateful to Muhammad Habibur Rahman for helpful insights.

Open Access This article is distributed under the terms of the Creative Commons Attribution License which permits any use, distribution, and reproduction in any medium, provided the original author(s) and the source are credited.

\section{References}

Aghion, P., and P. Howitt. 1992. A model of growth through creative destruction. Econometrica 60(2): 323-351.

Albala-Bertrand, J.M. 1993. Natural disaster situations and growth: A macroeconomic model for sudden disaster impacts. World Development 21(9): 1417-1434.

Barro, R.J. 1991. Economic growth in a cross section of countries. The Quarterly Journal of Economics 106(2): 407-443.

Barro, R.J., and J.-W. Lee. 1993. Losers and winners in economic growth. Working paper No. 4341, National Bureau of Economic Research (NBER), USA.

Barro, R.J., and X. Sala-i-Martin. 1992. Convergence. Journal of Political Economy 100(2): 223-251.

Brückner, M., and A. Ciccone. 2011. Rain and the democratic window of opportunity. Econometrica: Journal of the Econometric Society 79(3): 923-947.

Caballero, R.J., and M.L. Hammour. 1994. The cleansing effect of recessions. American Economic Review 84(5): 1350-1368.

Caselli, F., G. Esquivel, and F. Lefort. 1996. Reopening the convergence debate: A new look at cross-country growth empirics. Journal of Economic Growth 1(3): 363-389.

Cass, D. 1966. Optimum growth in an aggregative model of capital accumulation: A turnpike theorem. Econometrica: Journal of the Econometric Society 34(4): 833-850. 
Cavallo, E.A., A. Powell, and O. Becerra. 2010. Estimating the direct economic damages of the earthquake in Haiti. Economic Journal 120(546): F298-F312.

Cavallo, E., S. Galiani, I. Noy, and J. Pantano. 2013. Catastrophic natural disasters and economic growth. Review of Economics and Statistics 95(5): 1549-1561.

CRED (Centre for Research on the Epidemiology of Disasters). 2010. Em-Dat: International disaster database. Brussels: Centre for Research on the Epidemiology of Disasters, Université Catholique de Louvain.

Cuaresma, J.C., J. Hlouskova, and M. Obersteiner. 2008. Natural disasters as creative destruction? Evidence from developing countries. Economic Inquiry 46(2): 214-226.

Dacy, D.C., and H. Kunreuther. 1969. The economics of natural disasters: Implications for federal policy. New York: Free Press.

Durlauf, S.N., P.A. Johnson, and J. Temple. 2005. Growth econometrics. In Handbook of economic growth, vol. 1, ed. P. Aghion, and S.N. Durlauf, 555-677. Atlanta: Elsevier.

Ellson, R.W., J.W. Milliman, and R.B. Roberts. 1984. Measuring the regional economic-effects of earthquakes and earthquake predictions. Journal of Regional Science 24(4): 559-579.

Fisker, P.S. 2012. Earthquakes and economic growth. Working paper No. 01/2012. Development Research Working Paper Series. La Paz: Institute for Advanced Development Studies (INESAD).

Galor, O. 2005. From stagnation to growth: Unified growth theory. In Handbook of economic growth, vol. 1, ed. P. Aghion, and S.N. Durlauf, 171-293. Atlanta: Elsevier.

Galor, O., and D.N. Weil. 2000. Population, technology, and growth: From Malthusian stagnation to the demographic transition and beyond. American Economic Review 90(4): 806-828.

Gourio, F. 2008. Disasters and recoveries. American Economic Review 98(2): 68-73.

Hansen, G.D., and E.C. Prescott. 2002. Malthus to Solow. American Economic Review 92(4): 1205-1217.

Harberger, A.C. 1987. Comment. In National Bureau of Economic Research (NBER), Macroeconomics annual, ed. S. Fischer, 255-258. London: MIT Press.

Heston, A., R. Summers, and B. Aten. 2011. Penn world table version 7.1. Center for International Comparisons of Production, Income and Prices at the University of Pennsylvania.

Horwich, G. 2000. Economic lessons of the Kobe earthquake. Economic Development and Cultural Change 48(3): 521-542.

Kahn, M.E. 2005. The death toll from natural disasters: The role of income, geography, and institutions. Review of Economics and Statistics 87(2): 271-284.

Kahneman, D., and H. Kunreuther. 2008. Dealing with low probability-high consequence events: A behavioral economics of risk presentation. Economics of Disaster Risks Seminar Series. Washington, DC: World Bank.

Keefer, P., E. Neumayer, and T. Plümper. 2011. Earthquake propensity and the politics of mortality prevention. World Development 39(9): 1530-1541.

Koopmans, T.C. 1963. On the concept of optimal economic growth. Discussion papers. Cowles Foundation for Research in Economics, Yale University.

Kuznets, S. 1973. Modern economic growth: Findings and reflections. American Economic Review 63(3): 247-258.
Loayza, N., E. Olaberria, J. Rigolini, and L. Christiaensen. 2009. Natural disasters and growth going beyond the averages. Policy Research Working Paper Series: 4980. The World Bank.

Lucas, R.E. 1988. On the mechanics of economic development. Journal of Monetary Economics 22(1): 3-42.

Lucas Jr, R.E. 1990. Why doesn't capital flow from rich to poor countries? American Economic Review 80(2): 92-96.

Mankiw, N.G., D. Romer, and D.N. Weil. 1992. A contribution to the empirics of economic growth. The Quarterly Journal of Economics 107(2): 407-437.

Mill, J.S. 1848. Principles of political economy. London: John W. Parker.

Nakamura, E., J. Steinsson, R.J. Barro, and J.F. Ursua. 2010. Crises and recoveries in an empirical model of consumption disasters. Working paper No. 15920, National Bureau of Economic Research (NBER), USA.

Noy, I.M. 2009. The macroeconomic consequences of disasters. Journal of Development Economics 88(2): 221-231.

Noy, I., and T. Vu. 2010. The economics of natural disasters in a developing country: The case of Vietnam. Journal of Asian Economics 21(4): 345-354.

Okuyama, Y. 2003. Economics of natural disasters: A critical review. Research paper No. 2003-2, Regional Research Institute, West Virginia University.

Pelling, M., A. Maskrev, P. Ruiz, and L. Hall. 2004. Reducing disaster risk: A challenge for development. UNDP global report. New York: United Nations Development Program.

Raddatz, C. 2007. Are external shocks responsible for the instability of output in low-income countries? Journal of Development Economics 84(1): 155-187.

Ramsey, F.P. 1928. A mathematical theory of saving. Economic Journal 38(152): F543-F559.

Romer, P.M. 1986. Increasing returns and long-run growth. Journal of Political Economy 94(5): 1002-1037.

Rousseeuw, P.J., and A.M. Leroy. 1987. Robust regression and outlier detection. New York: Wiley.

Schumpeter, J.A. 1942. Capitalism, socialism and democracy. New York: Harper.

Skidmore, M., and H. Toya. 2002. Do natural disasters promote longrun growth? Economic Inquiry 40(4): 664-687.

Solow, R.M. 1956. A contribution to the theory of economic growth. The Quarterly Journal of Economics 70(1): 65-94.

Swan, T. 1956. Economic growth and capital accumulation. Economic Record 32(2): 334-361.

Temple, J. 1998. Robustness tests of the augmented Solow model. Journal of Applied Econometrics 13(4): 361-375.

Temple, J. 1999. The new growth evidence. Journal of Economic Literature 37(1): 112-156.

World Bank. 2013. World development indicators. Washington, DC: World Bank.

Yezer, A.M., and C.B. Rubin. 1987. The local economic effects of natural disasters. Working paper No. 61, Institute of Behavioral Science. Boulder: University of Colorado.

Zenklusen, O. 2007. Natural disasters and economic development: A neoclassical review of theoretical perspectives and empirical evidence. Thesis, University of St. Gallen. 